\author{
(online) $=$ ISSN $2285-3642$ \\ ISSN-L = $2285-3642$ \\ Journal of Economic Development, Environment and People \\ Volume 4, Issue 2, 2015 \\ URL: $\underline{\text { http://jedep.spiruharet.ro }}$ \\ e-mail: office jedep@spiruharet.ro
}

\title{
Global Risk Management - A Necessity in a World of Vulnerabilities and of ECO-Economy and BIO -ECO-Economy Needed by ECO-SANO-Genesis
}

\author{
Associate Professor Elena Gurgu PhD ${ }^{1}$, Assistant Lecturer Cosmina Savu PhD cd ${ }^{2}$ \\ ${ }^{1,2}$ Spiru Haret University
}

\begin{abstract}
The Vision of the Eco-Bio-Economy is to sustain development of the humankind welfare in all forms, through an economy of future dedicated to human life through the rational use of the environmental resources. The present work attempts to discuss the issues that humanity faces at the beginning of a new global economic paradigm. The minimum point of the financial crisis started in 2008 meets the final years of the decline phase of the long term global economic cycle. The feeling is one of lack of vision on the part of Governments, of improvisation, of passive reaction, such as seeing and doing. One feels that the economic context is worn out, dysfunctional because of deep recovery problems. The perception, not far from the taugh reality, is that of a national competition meant to minimize losses caused by the financial crisis and to use beggar thy neighbor types of policies, similar to finding the way out of the crisis on the expense of others.
\end{abstract}

Keywords: world financial and economic crisis, global risks, unemployment, inequality, globalization, conflicts, chronic unemployment, eco-bio-economy, global economic and financial crisis, global risks, unemployment, inequality, globalization, conflicts, chronic underemployment, green economy

JEL Codes: A11, D81, E24, E27, F01, F02, F62, G01, H12, J50

\section{Introduction}

UNEP-United Nations Environment Program (environment for development) has developed a working definition of the Green Economy as an economy that may have results in improved human well-being and social equity, while significantly reducing environmental risks and ecological scarcities. Ecological policies became throughout times, a constant attitude of the world governments, as much as the ecological and the biodiversity interferences of the regional, national, transnational and global interdependencies, affect all nations. Eco-Bio-Economy is a scientific, economic and philosophic endeavour dedicated to the development of the integrated environment health, of the mankind welfare, through an integrated

\footnotetext{
${ }^{1}$ E-mail address: elenagurgu@yahoo.com

${ }^{2}$ E-mail address: mailto:cosmina.savu@yahoo.com
} 


\author{
(online) $=$ ISSN $2285-3642$ \\ ISSN-L = 2285 - 3642 \\ Journal of Economic Development, Environment and People \\ Volume 4, Issue 2, 2015 \\ URL: http://jedep.spiruharet.ro \\ e-mail: office jedep@spiruharet.ro
}

multipolar eco-bio-economic concept, which promotes the Agrifood Green Power and the Smart Sustainable Integrated Development of the future. "Eco-Bio-Economy is an economy of the future, in the service of human life by rational use of environmental resources", prof. Dr. dr.h.c. Alexandru T. Bogdan, member of the Romanian Academy, claims to several national and international conferences and publish in international speciality literature, an attempt to unite the two concepts: Eco-Economy, by Lester Brown and Bio-Economy, by Nicholas Georgescu Roegen, a new paradigm Eco-Bio-Economy. Eco-Bio-EconomicSafety directed to the economic, biodiversity, food security and food safety aspects, introduces - the new syntagm of the Eco-Bio-Economic Food Safety, to define also to a new syntagm - the Eco-Bio-Economic Social Safety, focusing the Customer Satisfaction and equally the Customer Protection, considering that food safety and social security have among other important objectives, a common target - customer satisfaction and its protection- and in extension, all interested parties.

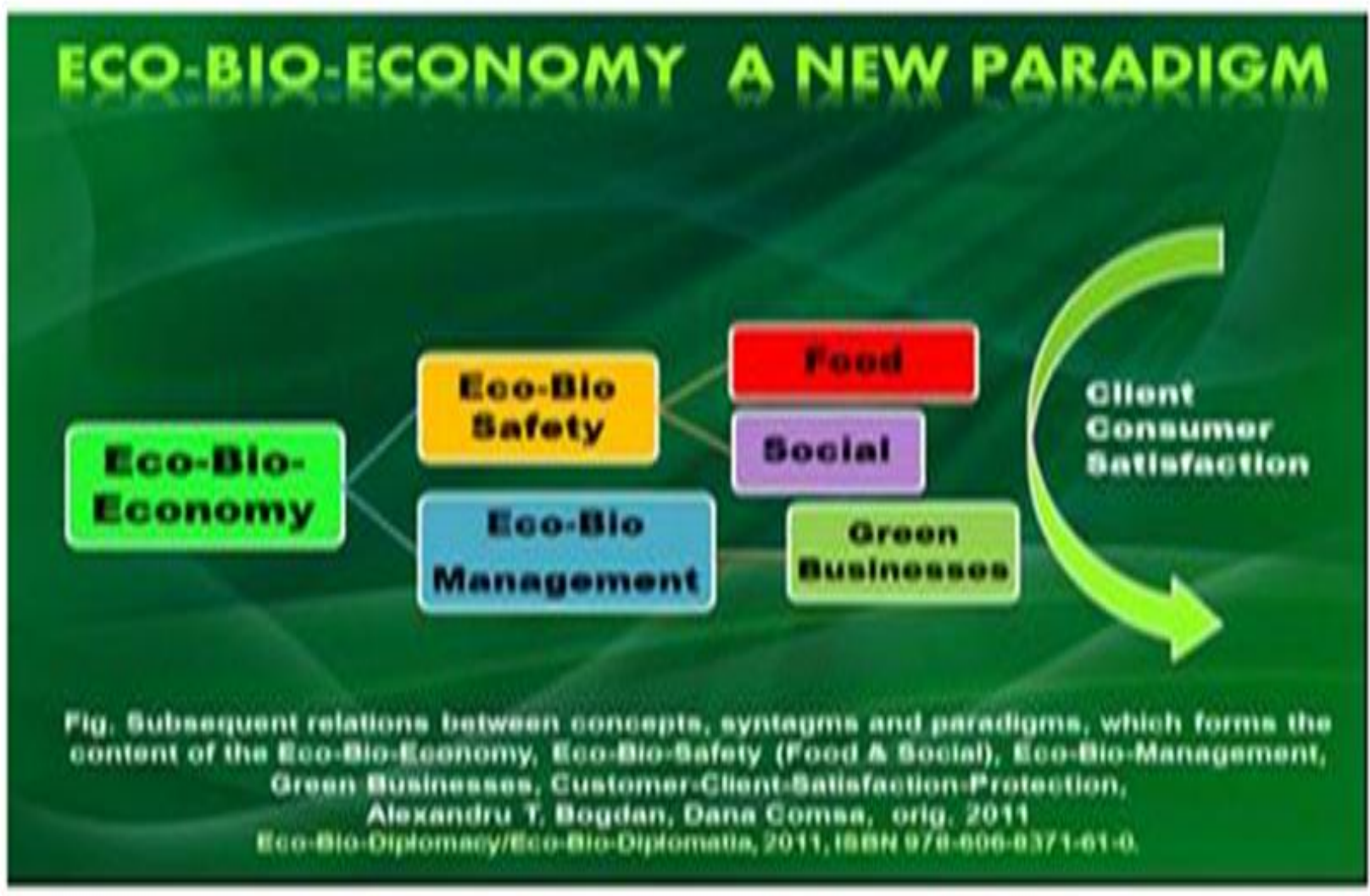

Fig.no. 1- Subsequent relations between concepts, syntagms and paradigms, which forms the content of the EcoBio-Economy, Eco-Bio-Safety (Food \& Social), Eco-Bio-Management, Green Business, Customer-Client-SatisfactionProtection

Source: A.T. Bogdan, Dana Comşa orig. May 2011

The Eco-Bio-Management is a Smart Sustainable Management (SSM) defined as an eco-biomanagement of future, eco-bio-sustainable, smart, harmonious, integrated and innovative, dedicated to the smart sustainable development and to the eco-bio-continuous improvement, welfare and the quality of 


\author{
(online) $=$ ISSN $2285-3642$ \\ ISSN-L = 2285 - 3642 \\ Journal of Economic Development, Environment and People \\ Volume 4, Issue 2, 2015 \\ URL: http://jedep.spiruharet.ro \\ e-mail: office jedep@spiruharet.ro
}

life improvement, through innovative and rational use of the environmental resources. The syntagm Smart Sustainable Development is addressing to the holistic development through the concepts linked with the eco-bio-economy, innovation and quality. The syntagm Integrated Smart Sustainable Development is launched in order to stimulate the interrelation between concepts as eco-economy, bio-economy, economy, biology, biodiversity, ecology, green quality, together with new approaches as eco-bio-economy, agrifood green power, international diplomacy, global economy, sustainable development.

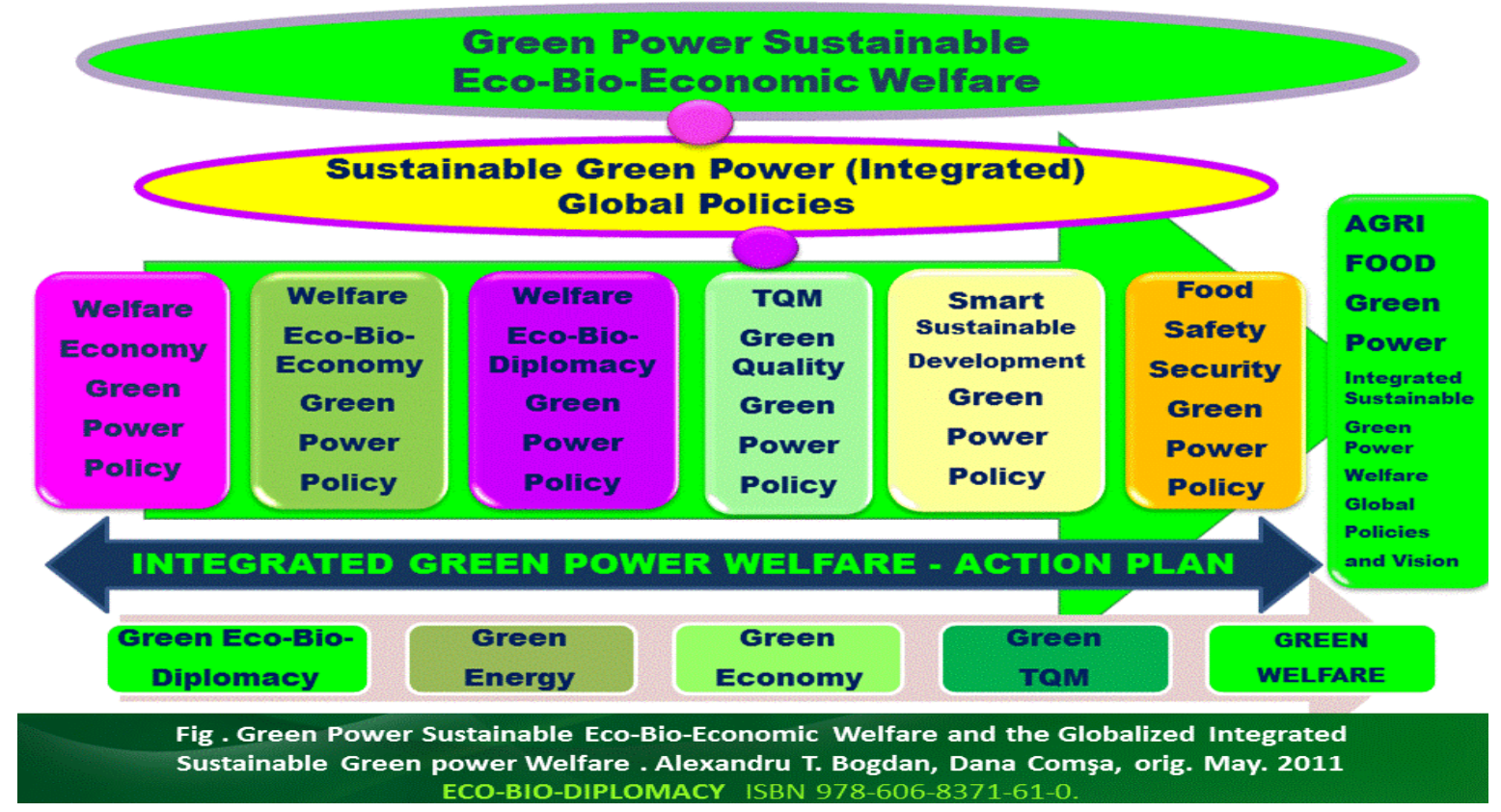

Fig. no. 2 - Smart Integrated Sustainable Green Power in the Eco-Bio-Economy context

Source: A.T. Bogdan, Dana Comşa orig. May 2011

In the context of the eco-bio-economic thinking, univ. prof. PhD Dr. h.c. Alexandru T. Bogdan, correspondent member of the Romanian Academy, initiator of the Eco-Bio-Economy, introduced the new concept of the Integrated Environment Health in a globalized world, as an Olympic health, a multidimensional, global, integrative health, a healthiness of people, plants, animals, water, soil, air, for a healthy environment: "a healthy mind, in a healthy body, in a healthy world, with a healthy environment", (orig. A.T. Bogdan, May 2011). 


\author{
(online) $=$ ISSN $2285-3642$ \\ ISSN-L = $2285-3642$ \\ Journal of Economic Development, Environment and People \\ Volume 4, Issue 2, 2015
}

URL: http://jedep.spiruharet.ro

e-mail: office jedep@spiruharet.ro

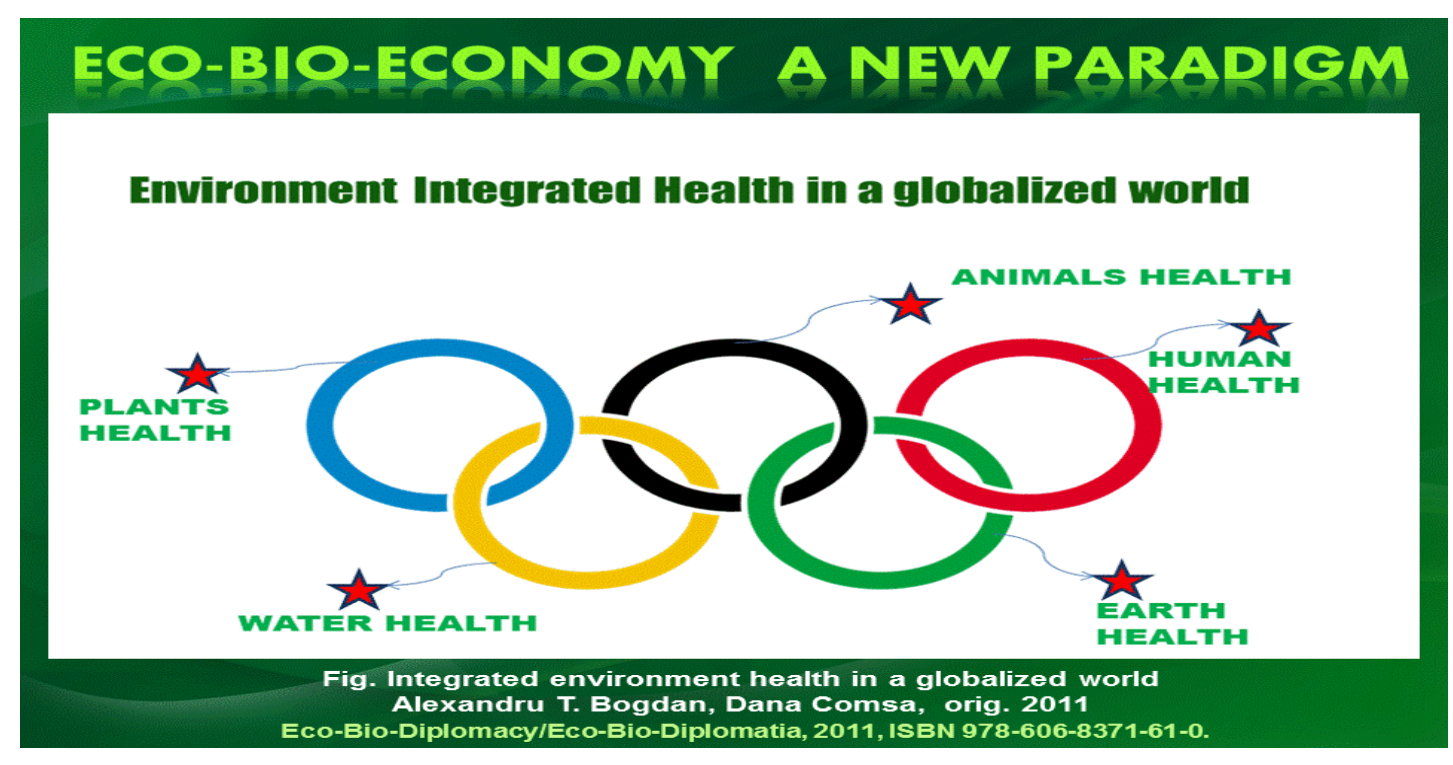

Fig. no. 3 - Integrated environment health in a globalized world

Source: A.T. Bogdan, Dana Comşa orig. May 2011

Eco-Bio-Economy may be considered an attempt for a new eco-economic and bio-economic vision, which reunites in an integrated pattern: the economy, the ecology, the biodiversity, the eco-economy and the bio-economy focusing the integrated smart sustainable development of the world. To this valuable areas, the Eco-Bio-Economy may address possible Eco-Bio-Policies and Eco-Bio-Strategies and allows the contribution of the social economy, of excellence and of the "all in one quality", of the welfare economy, of solidarity, social corporate responsibility, as elements which may be utilized in an integrated practical future platform in a multipolar world for a healthy and ecological environment, to ensure and to promote a smart, creative, innovative, economic sustainable development. The use of the decision-making process at the highest level and the modern diplomatic tools are the expected and needed catalytic agent for a global eco-bio-policy and eco-bio-economic successful equation.

The world financial and economic crisis of 2008-2009, whose effects are still felt in the present, the intensification of "currency wars", the spy scandals, the escalation of the armed conflicts and terrorist acts, have all contributed to a rise of global risks, uncertainty and vulnerability of the economies of the world.

2013 was a modest year for the global economy. The economic growth estimated at only $2.1 \%$ means very little and confirms the statements regarding the "secular stagnation" or the "winter"phase" of longterm Kondratieff cycles. The European Union has passed through a phase of stagnation in2013 $1+0.1 \%$ estimate), while China grew by $8 \%$, the U.S. increased by $1.9 \%$. Japan had an encouraging $+1 \%$ in 2013 . Forecasts for 2014 are more optimistic, showing a gradual comeback, with $+1.6 \%$ in the EU $28,+1.6 \%$ in Japan, $+8.1 \%$ in China. 


\author{
(online) $=$ ISSN $2285-3642$ \\ ISSN-L = 2285- 3642 \\ Journal of Economic Development, Environment and People \\ Volume 4, Issue 2, 2015 \\ URL: http://jedep.spiruharet.ro \\ e-mail: office jedep@spiruharet.ro
}

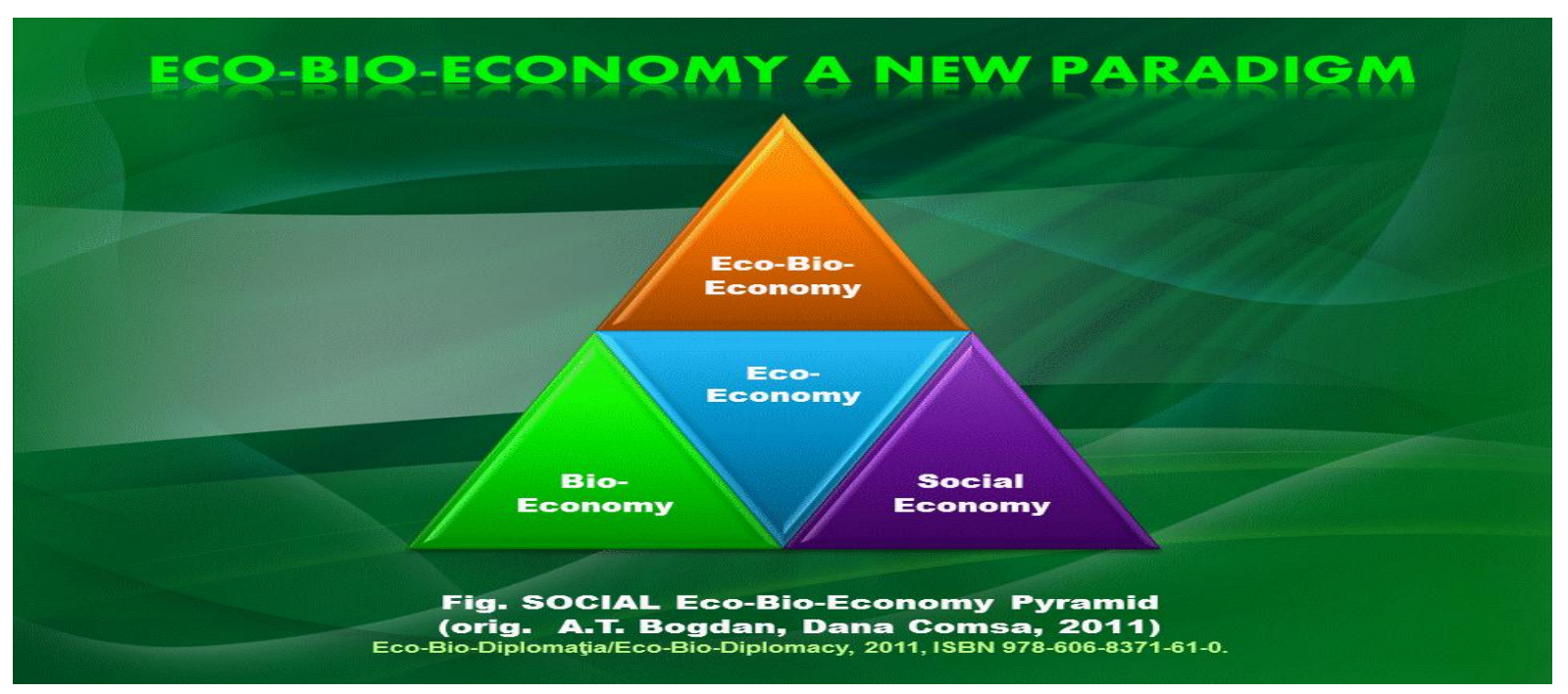

Fig. no. 4 - Social Eco-Bio-Economy pyramid

Source: orig. A.T.Bogdan, Dana Comşa, May 2011

The rapid changes in the 21st century at the level of infrastructure systems, more efficient and faster communications (Internet) have generated the development of closer relations between the countries, economies and companies, as well as tighter commercial and investment relations. The developments in the economic, social, geopolitical and technological environments have entailed unprecedented economic opportunities, but the interconnections between them have also involved great systemic risks.

\title{
2. Globalization: risks, uncertainties and vulnerabilities
}

Global emerging risks affect both Governments and stakeholders from all sectors of business. In order to manage them effectively and to develop a resistance to cope with their impact, we have to understand, to measure and to forecast the interdependence of these emerging global risks by expanding and diversifying the traditional instruments of risk management.

The report on global risks, for 2014 submitted within the framework of the World Economic Forum in Davos has a comprehensive risk analysis. It seems that the most important categories of global socialeconomic risks identified, depending on the level of the generated concern, probability, impact and connection between them are:

1. The fiscal crises in the developed economies of major countries (high degrees of indebtedness expressed through the public debt in relation to the GDP in the USA, Japan, eurozone countries). The developed economies are still in danger, while many emerging markets have experienced an increase in such activities in recent years, which could fuel the financial crisis. A fiscal crisis in any of the major economies could easily have a global domino-like effect. 


\author{
(online) $=$ ISSN $2285-3642$ \\ ISSN-L = 2285-3642 \\ Journal of Economic Development, Environment and People \\ Volume 4, Issue 2, 2015 \\ URL: $\underline{\text { http://jedep.spiruharet.ro }}$ \\ e-mail: office jedep@spiruharet.ro
}

2. High unemployment (especially among youth) and chronic under-employment in the labour market, both in developed and emerging economies. Unemployment represents a global risk given that numerous people both in advanced economies, as well as in emerging ones fail to find employment. Unemployment among young people, the most vulnerable category, reaching $50 \%$ in some countries and underemployment on the labour market prevails, especially in emerging countries and in the developing world. The high rate of structural unemployment and the low rate of employment in distressed countries (e.g. Spain)-are considered to be the most serious after the effects of social, economic and political effects generated by the financial crisis.

3. The crisis of drinking water resources is increasingly being acknowledged on the background of improper administration and growing competition for already scarce resources. In our opinion, any decision relating to the exploitation of other natural resources including shale gas, must take account of this major challenge, because sustainable development means meeting the needs of the present without compromising the ability of future generations to meet their own needs.

4. Severe disparities of income. There are also concerns about the negative effects of the financial crisis for the middle class in the developed economies, while globalization has resulted in the polarization of incomes in emerging countries and in the developing world.

5. Failure to mitigate and adapt to climate change. Even if governments and corporations are required to take measures in order to reduce the greenhouse effect, what's at stake is not only alleviating climate change, but also adjusting to them. The failure of the adaptation affects especially the least developed countries.

6. Increasing frequency - and intensity of extreme climatic phenomena (e.g., flooding, storms, hurricanes, typhoons, fires). Climate changes generate instability, leading to a higher frequency of extreme phenomena, such as floods or drought. The implications of these phenomena in terms of food security and social and political stability are strong enough.

7. Failures of global governance. The risk of a failure of global governance is believed to be connected in the largest extent with other global risks. International institutions, weak or inadequate in correlation with competing national and political interests, prevent cooperation in order to eliminate threats.

8. Food Crises. A food crisis occurs when access to a certain amount and quality of food is poor or unsafe. Food crises are closely related to risks relating to climate change and associated factors.

9. Failure of major financial institutions and mechanisms. Five years after the collapse of the Lehman Brothers, the collapse of such institutions is also a cause for concern, given that the uncertainties persist regarding the quality of many of the banks' assets.

10. Deep political and social instability. There is a risk that one or more critical countries in terms of systemic risk to experience a significant erosion of trust and mutual obligations between states and citizens, which could lead to the collapse of the state, domestic violence, regional or global instability and, possibly, to a military conflict. 


\section{(online) $=$ ISSN $2285-3642$ \\ ISSN-L = 2285 - 3642 \\ Journal of Economic Development, Environment and People \\ Volume 4, Issue 2, 2015}

URL: http://jedep.spiruharet.ro

e-mail: office jedep@spiruharet.ro

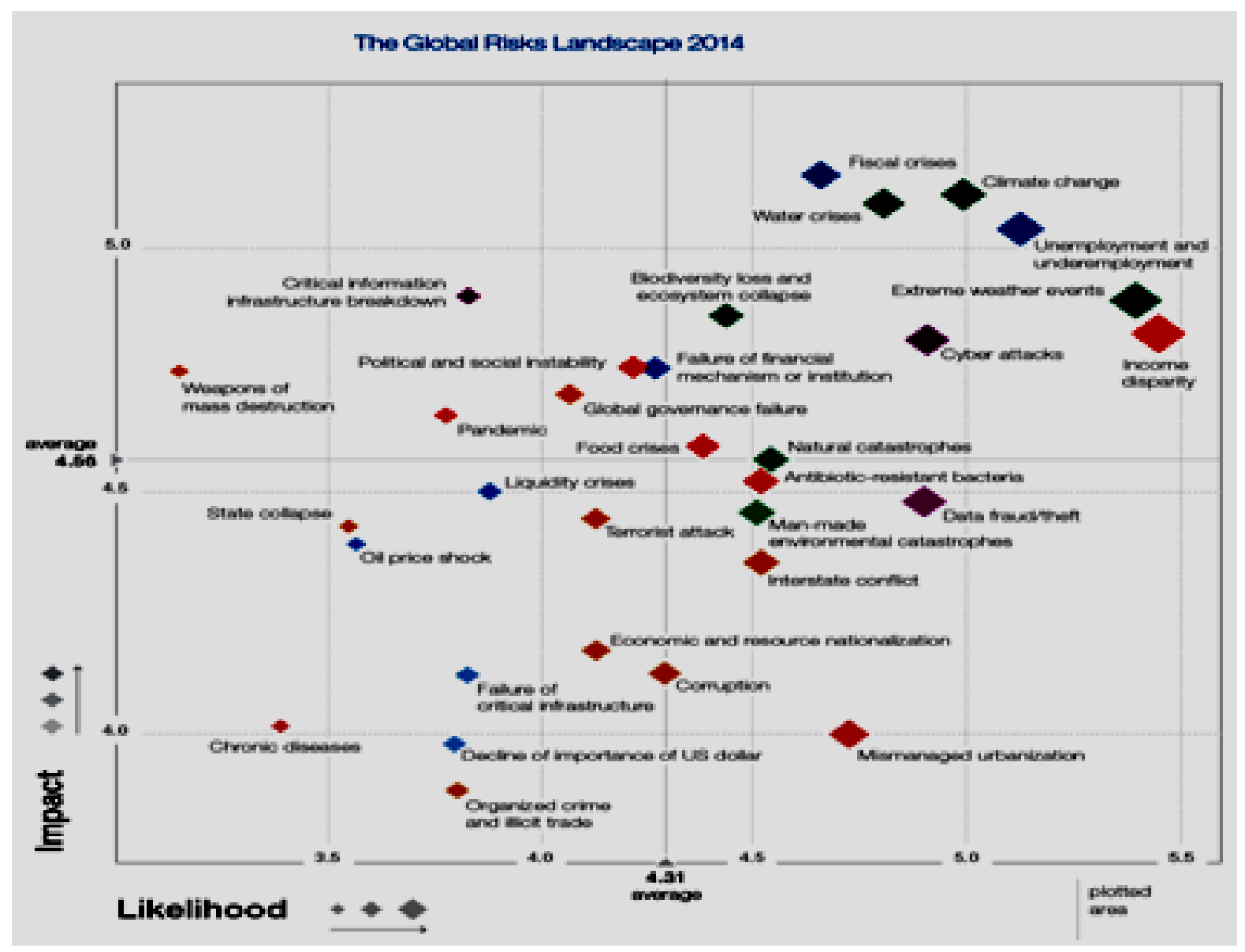

Figure no. 5. The Global Risks Landscape in 2014

Source: "World Economic Outlook" published by the IMF on January 21, 2014

Of these, three risks fall into the category of economic risks $(1,2,9)$, three are environmental hazards $(3,5,6)$, three social risks $(4,8,10)$ and one is a geopolitical risk $(7)$.

Such risks are often interrelated with each other, generating instability and, more importantly, interfere with other major challenges that accompany the "reset world order".

Narrowing down the analysis, a survey conducted by Earnst \& Young among some companies from 21 countries, both in developed markets and emerging ones, gives us a clearer picture of the risks and opportunities. The study examines in detail how companies address the present and future challenges and opportunities, presents and identifies the top 10 risks and opportunities for the period 2013-2015, in various sectors. Risk rating indicated by the respondents, although stable during the first part, fluctuate in the second part while the scoring of opportunities is much more balanced.

In the first part of the leader board, the top five ranked risks for 2013 and 2015 are similar: (1)pressure on prices; (2) reducing costs and pressure on profit; (3)market risks; (4) the macro-economic risk-weak or volatile prospects of economic growth and (5) management of talent and skills shortages. In the second 


\author{
(online) $=$ ISSN $2285-3642$ \\ ISSN-L = $2285-3642$ \\ Journal of Economic Development, Environment and People \\ Volume 4, Issue 2, 2015 \\ URL: $\underline{\text { http://jedep.spiruharet.ro }}$ \\ e-mail: office jedep@spiruharet.ro
}

part of the top, one can notice some changes: extending the role of Government in the economy-6th place in 2013, will descend on the7th place in 2015; Regulation and compliance-7th place in 2013, climbs to 6th place in 2015; sovereign debt and the impact of fiscal austerity or sovereign debt crisis descends on the 8th place in 2013 and 10th place in 2015; the importance of emerging technologies ranked 9th in 2013, is at number eight for 2015 and the shocks caused by the political changes is climbing from position 10 in 2013 to 9 in 2015.

Somewhat similar to the risk ladder, the ladder of opportunities, this time, the first six items remain the same for both 2013 and 2015.

Thus, innovation in products (1), increased demand in emerging markets (2), investment in business processes, tools and training to achieve greater productivity (3), new marketing channels (4), improving the strategy of implementation in all business functions (5), investments in IT (6). Improving investor relations descends from a-7th place in 2013, to the 8th position in 2015. CSR programs and the increase of public confidence climbs one position, from 8th place in 2013, to 7th place in 2015. Investments in green technologies and global optimizations and relocation of key functions remain in the same positions for 2013 and 2015, respectively, on 9 and 10.

The chronic gap between the incomes of the rich and the poor citizens of the world is seen from the Davos report as being most likely to cause serious injury risk worldwide. Analyzing the most likely evolution of humanity over the next 10 years, the report classified in five categories-environmental, economic, social, geopolitical and technological potential risks, and evaluate them in terms of likelihood and impact potential.

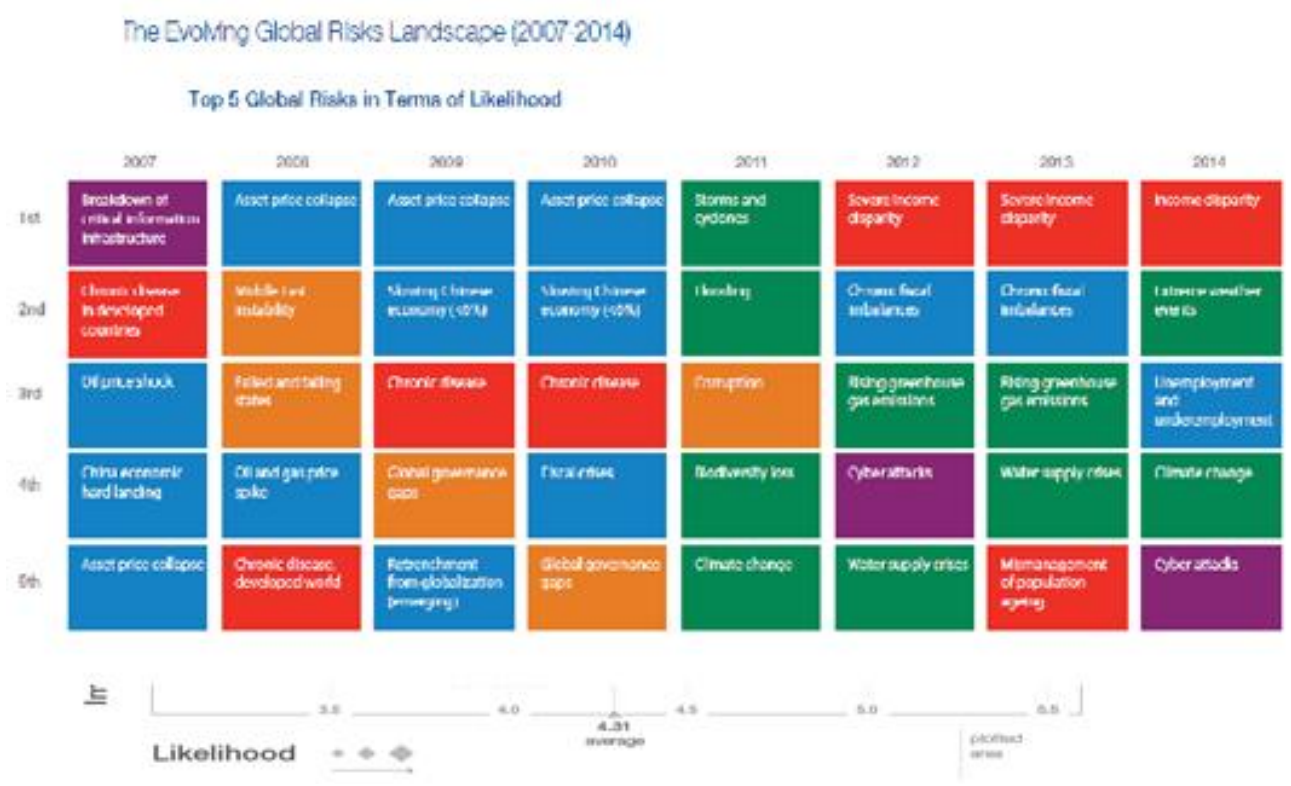

Table no. 1. The Evolution of the most important 5 global risk factors in terms of likelihood in the period 20072014 


\author{
(online) $=$ ISSN $2285-3642$ \\ ISSN-L = 2285- 3642 \\ Journal of Economic Development, Environment and People \\ Volume 4, Issue 2, 2015 \\ URL: http://jedep.spiruharet.ro \\ e-mail: office jedep@spiruharet.ro
}

Source: "World Economic Outlook" published by the IMF on January 21, 2014

The most likely global threats after the gap of incomes. The World Economic Forum's experts consider severe weather events as being most likely to provoke "a systemic shock of global scale". These are followed by unemployment and underemployment, climate change and cyber attacks.

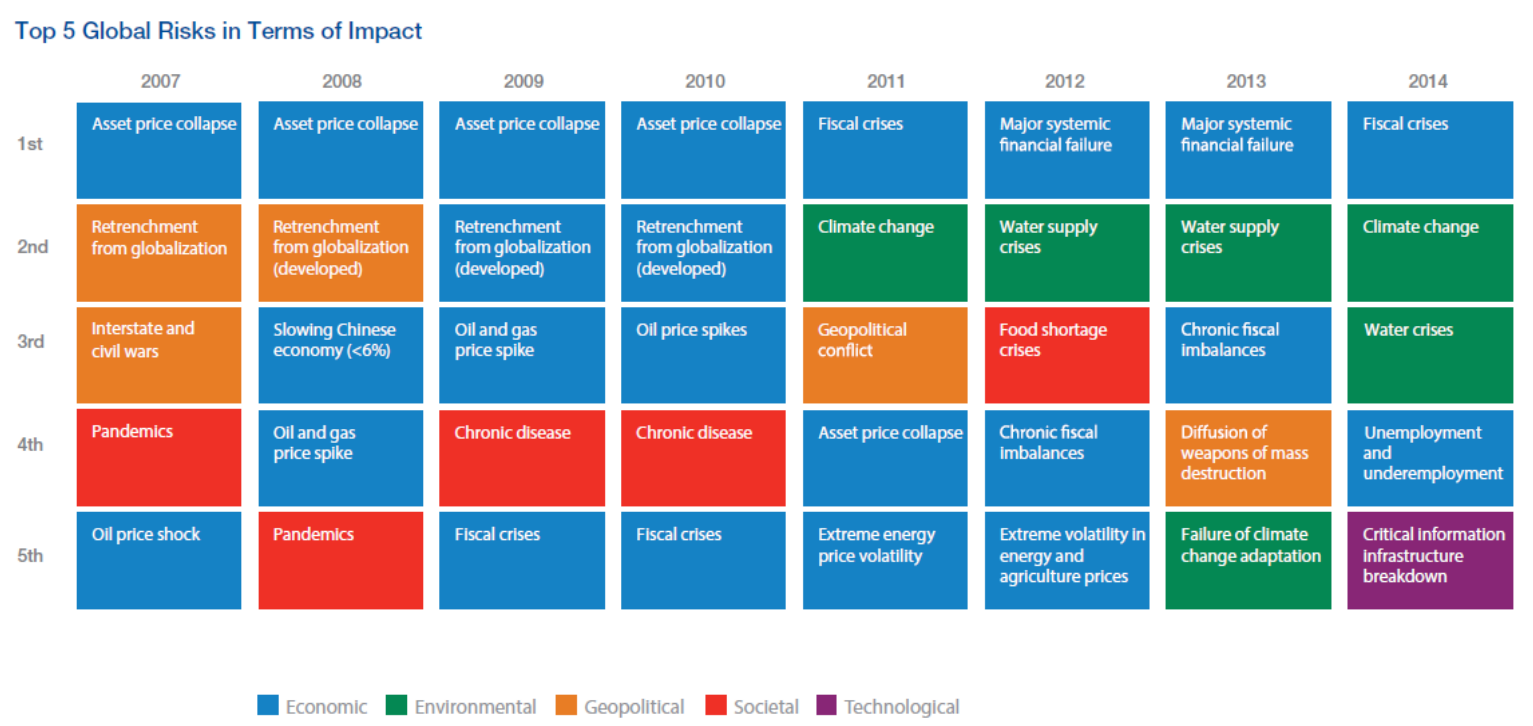

Table no. 2. The evolution of the most important 5 global risk factors in terms of impact in the period 2007-2014

Source: "World Economic Outlook" published by the IMF on January 21, 2014

The threats with the most destructive impact, that is the financial crises, are considered to be those that can affect most severely the systems and the states. The economic risk is followed by two risks in the category of environment-climate change and drinking water crisis, a social one (unemployment and underemployment) and a technological one (the collapse of essential communications infrastructure).

Each report has analysed the risks potentially worldwide, but their inter-relationship (they can become active at the same time or in a cascade effect and can lead to a multiplied effect. It is vital, therefore, that the rich and the world's policy makers should address these risks in a deeply responsible manner (according to Jennifer Blanke, the World Forum's Chief Economist). 


$$
\begin{gathered}
\text { (online) }=\text { ISSN } 2285-3642 \\
\text { ISSN-L = 2285 - 3642 } \\
\text { Journal of Economic Development, Environment and People } \\
\text { Volume 4, Issue 2, } 2015
\end{gathered}
$$

URL: http://jedep.spiruharet.ro

e-mail: office jedep@spiruharet.ro

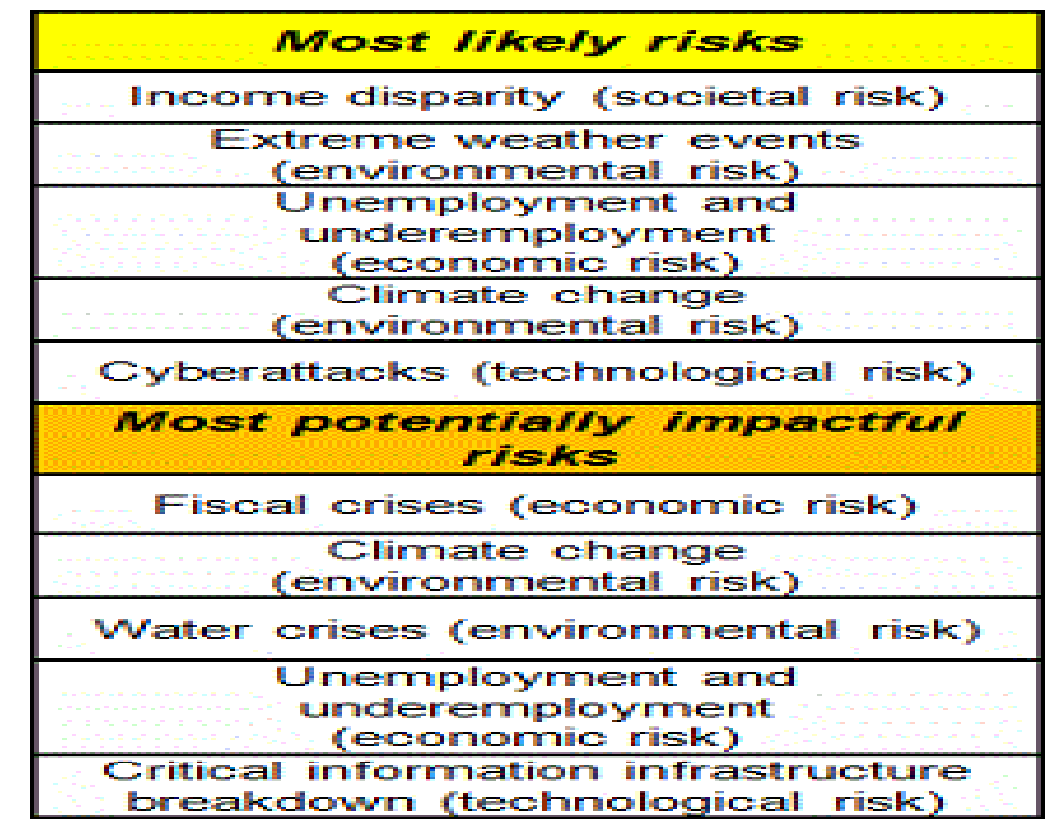

Table no. 3. Major global risks in terms of likelihood and potential impact

Sursa: "World Economic Outlook" published by the IMF on January 21, 2014

\section{The major threats of an economic, geopolitical, social and environmental nature}

In this part of the paper we aim to bring to the fore some of the major threat of an economic, geopolitical, social and environmental nature threatening the world by presenting some opinions expressed by high officials of states such as the Japanese Prime Minister, the Chinese Minister of Foreign Affairs, the US Secretary of State, the British Prime Minister, the President of Brazil and the Iranian President.

Japan. The Japanese Prime Minister Shinzo Abe, has "a new vision for a new Japan",highlighting the two main aspects: the economic strategy of the three arrows"(orAbenomie $=$ Abe + Economics) and ensuring peace in the Asian seas. In Japan, the last 15 years of deflation have led to the stagnation of domestic economy, amid discouraging investment and new projects and, at the same time, the increase of the public debt. In December 2013, the Government approved a record budget for the fiscal year that began on April 1, 2014, valued at 96,000 billion yen (921 billion dollars). The economic strategy "of the three arrows" is based on an aggressive monetary policy, a flexible fiscal policy and a structural reform of the economy. The three arrows refer to the legend of Mori Motonari, a Japanese feudal senior from the 16th century, who gave his sons a lesson by showing them that, while an arrow is easily broken, the same thing cannot be said about a clump of three arrows. The moral is this: those who are united and invincible.

A major challenge is the fast aging of the population, having as a direct consequence the reduction of the workforce. The electricity market reform (the first such reform in the past 60 years) in three stages, which will be complete until the opening of the Tokyo Olympic Games of 2020 (to consult and report on the 


\author{
(online) $=$ ISSN $2285-3642$ \\ ISSN-L = $2285-3642$ \\ Journal of Economic Development, Environment and People \\ Volume 4, Issue 2, 2015 \\ URL: http://jedep.spiruharet.ro \\ e-mail: office jedep@spiruharet.ro
}

first year of the administration of Abe, January 2014). At the same time, the Government seeks to eliminate restrictions on home production of rice (in force for over 40 years), health system reform, the reform of the labour market (including increasing the role of women and acceptance of foreign employees), building cities with zero emissions of gases and with no greenhouse effects. Externally, considering the deepening integration of Japan in the global knowledge flows, trade and investment, by completing the trans-pacific partnership and the conclusion of the EU-Japan economic partnership. The Prime Minister believes that "Asia has become a center of growth for the entire world. Japan is surrounded by neighbors with unlimited possibilities, such as China, South Korea, ASEAN, India and Russia, and in the Pacific, the partner countries of the transpacific Partnership ". He highlighted the need for the restriction of military expansion in Asia and the transparency of the military budgets. The reference to peace in the Asian seas is an indirect message to China, taking into account the increase of its military strength and intensification of territorial disputes in the East China Sea.

China. The Chinese Minister of Foreign Affairs Wang Yi, focuses on the current reform "for the benefit of the whole world" and the strengths of the Chinese economy, such as the milleniums old culture and traditions and strength of the Communist Party, with 86 million members,"united as one" which lend Chinese features to the capitalist development model in the People's Republic of China. The weaknesses of the Chinese system are the existing disparities between urban and rural places, but also between regions. In the geopolitical sphere, Wang Yiplann emphasizes China's contribution to global peace, through its "peaceful" way of development, deeper involvement of his country in resolving disputes and conflicts and international opposition against holding any form of aggression. The renewal of the Chinese "dream of fulfillment" (which reminds us of the American dream) are "good for China and for the entire world".

USA. The US Secretary of State, John Kerry firmly rejects the accusation that "the US would withdraw from global affairs" as arguments, bringing the active involvement of his country in three of the most pressing issues in the Middle East: Iran's nuclear program, the war in Syria and the Israeli-Palestinian conflict. He said that no state in the world has invested so much effort in this region. At the same time, he depicted the progress of the US on EU economic integration path (hinted at the transatlantic partnership for trade and investment under negotiation) and other similar initiatives, such as the transpacific partnership.

The United Kingdom. The British Prime Minister David Cameron, refers to the process opposed to outsourcing, which is bringing" some jobs back in the West from the East, so that the benefits of globalization shall return "home". According to opinion polls conducted among small entrepreneurs, one in ten Britons began producing again in the United Kingdom. In the US, a similar survey showed that over one third of entrepreneurs is planning to move their manufacturing facilities from China to the US. In this context, the British Prime Minister mentions that one of the important factors of the "internalisation" and at the same time, economic growth is the exploitation of shale gas. The British Prime Minister may probably consider the election results in $\mathbf{2 0 1 5}$ more important than the fate of the environment and the planet. Referring to the relationship with the EU, Cameron shows that it is necessary 'to reform the EU and to reform the UK's relationship with the EU".

Brazil. Dilma Rousseff, Brazil's President put emphasis on attracting investments, which are welcome in the context of poverty eradication and the strengthening of the middle class (which has increased in 


\author{
(online) $=$ ISSN $2285-3642$ \\ ISSN-L = $2285-3642$ \\ Journal of Economic Development, Environment and People \\ Volume 4, Issue 2, 2015 \\ URL: $\underline{\text { http://jedep.spiruharet.ro }}$ \\ e-mail: office jedep@spiruharet.ro
}

number with 42 million in 2003). Referring to short-term volatility generated by the more restrictive monetary policies in developed countries, it said that Brazil is ready, with foreign reserves worth 370 billion dollars and, more important Brazil benefits from economic recovery advanced economies. Rousseff is in favour of liberalisation, claiming both the Doha round, as well as negotiations for the conclusion of a free trade agreement between EU and Mercosur.

Iran. The Iranian President Hassan Rouhani (in Office from August 2013) focuses on economic growth and the goal of his country to become one of the top ten economies of the world in the years to come. He stressed the desire to have peace relations with both its neighbors and the world. Referring to the preliminary agreement on Tehran's nuclear program in Geneva within th P5 +1group (the United States, Britain, France, Russia, China and Germany), Rouhani emphasized that he sees no obstacles, insurmountable impediments or barriers that might hinder the conclusion of a comprehensive agreement in the future.

\title{
4. The Perspectives of the World Economy
}

This section is based on data from the "World Economic Outlook" published by the IMF on January 21, 2014. For a full analysis of the situation of the global economy, I consulted the World Bank Report, "Global Economic Prospects" and the UN report, Global economic situation and prospects", January 2014.

The founder and president of the World Economic Forum in Davos, Klaus Schwab, is of the opinion that the current global context is characterized by "low expectations" and "more unknown variables". He held that, in the next 5-10 years, the world economy will grow slowly, and the pace of growth will not return anytime soon to the levels prior to the crisis. At Davos was mentioned the risk of a dark European scenario on the long-term, with a slow economic growth(around $1 \%$ per annum), with high structural unemployment (between 9 and 11 percent of the active population) and with a public debt of around $100 \%$ of the GDP.

The Director general of the IMF, Christine Lagarde, said in Davos that there are "old" threats (the failure of reforms of the banking system and reducing economic imbalances) and "new threats" that hung over the global economy, and the crisis has not ended. Indeed, this fact is also confirmed by the recent turmoil in emerging markets, especially in Argentina andTurkey, where the Peso and the Pound have suffered massive devaluations, but also from countries such as Brazil, India, Indonesia, the Republic of South Africa (four, alongside Turkey, being known in May 2013 as "the five fragile economies"- the name given by specialists from the Morgan Stanley- on the background of the current account deficits recorded by these, which makes them vulnerable to outflows of "hot capital").

The Director general of the IMF called for caution in regard to speculative bubbles and warned that the economic recovery is accompanied by imbalances, with high unemployment and deflation risks. LaGarde warned that low inflation in advanced countries, in particular in the Euro area (with a rate of inflation of $0.8 \%$, below the European Central Bank's target of $2 \%$ ), could have unpleasant consequences in terms of funding costs and indebtedness, both for Governments and companies. At the same time, it stressed that greater social inequalities are less sustainable economic growth. 


\author{
(online) = ISSN $2285-3642$ \\ ISSN-L = 2285-3642 \\ Journal of Economic Development, Environment and People \\ Volume 4, Issue 2, 2015 \\ URL: $\underline{\text { http://jedep.spiruharet.ro }}$ \\ e-mail: office jedep@spiruharet.ro
}

The European Commissioner for Economics and Monetary Affairs Olli Rehn stated that he was aware of the risks, but also good developments have started to be noticed inEurope.

The IMF report on the world economic forecast, published before the meeting in Davos, estimates a revival of the economic activity in 2014-2015 (increases of 3.7 percent and3.9 percent), respectively, on the background of the recovery of developed economies. The developed economies as a whole expect a, GDP growth forecast at 2.2\% 2.3\% in 2014 and in 2015 (compared with 1.3\% in 2013), a higher rate than average is expected in countries like the USA, UK and Canada, and below average in the Euro area and in Japan. The IMF analysis shows that, in developed countries, the gap remains high, and, taking into account existing risks (for example, deflation), it is recommended that a flexible monetary policy, while fiscal consolidation must continue.

The slowing down of the Chinese, which is considered economy-global, economic growth engine, is a cause for concern for experts. However, the growth of Chinese GDP are still robust, the IMF forecasts levels of 7.5\% in 2014 and 7.3\% in 2015. For 2014-2015, the IMF experts forecast that the pace of economic growth in India will exceed the average pace of emerging economies, in contrast to the Republic of South Africa, Brazil and Russia, with rhythms under the media group said.

IEM experts considers that, at the level of BRICS, along with engines of economic growth such as exports and FDI attracted in the last period looms ever more poignantly complementary engines: domestic demand (spurred by the high level of remittances of Russian citizens abroad in countries such as China and India), making investment overseas, boosting innovation and infrastructure development.

\title{
5. Climate change
}

Within the framework of the world economic forum in Davos last year, January 24, has become "The Climate Day", being reserved for the theme of climate change, to encourage world leaders to engage firmly in the fight against this global threat.

Ban Ki-moon, the Secretary-General of the United Nations (UN), drew attention to climate change and the need to move from "the brown" to the "green" economy. In his view, this transformation requires: (1) support from the financial sector (investors, banks, other financial institutions), (2)decrease in financial resources allocated to old technologies, (3)increase transparency with regard to the emission of greenhouse effect gases, associated assets and sectors that investors and banks, finances (4) cooperation between banks,investors and those in the regulation, so as to ensure that the rules governing financial markets, supports sustainable development. In this context, Ban Ki-moon has highlighted that the climate Summit, which will take place in New York in September 2014 under the aegis of the UNITED NATIONS, constitutes a significant step towards the signing of a treaty in 2015 with legal binding force, The Agreement-on global climate change.

The World Bank President Jim Yong Kim said in turn that despite the measures taken in the"green economy," emissions of greenhouse gases continue to increase, while the poor suffer further. In his opinion, there is no need of leaders who think in terms of short term benefits or electoral cycles, but 


\author{
(online) = ISSN $2285-3642$ \\ ISSN-L = 2285-3642 \\ Journal of Economic Development, Environment and People \\ Volume 4, Issue 2, 2015 \\ URL: $\underline{\text { http://jedep.spiruharet.ro }}$ \\ e-mail: office jedep@spiruharet.ro
}

leaders who take into account the most vulnerable of present and future generations. At the same time, we need a plan to deal with the whole problem of climate change and possible solutions.

Jim Yong Kim said that the imposition of a tax on pollution as well as performance standards for buildings, vehicles, transportation systems, technologies, so that "cleaner and greener ones should be encouraged". According to the IMF study "Reforming Energy subsidies: lessons and implications" of 27 March 2013, subsidies for fossil fuels stands at 1,900 billion dollars worldwide. However, this sum may be forwarded to the investment in green energy. The President of the World Bank believes that a prime objective in the short term may be to encourage the green certificates market may reach $\$ 20$ billion up to September's Summit in New York, and at $\$ 50$ billion to the United Nations Conference on climate change this year in Paris (COP 21).

\title{
6. Gradual withdrawal of monetary stimuli by the FED of the USA, with effects on emerging economies
}

Statistics show that, at the time of Janet Yellen's coming to Ben Bernanke on February 1, 2014, the US Central Bank's assets, the FED, rose to 4,100 billion dollars (of which a percentage of $37 \%$ were represented by the securities backed by mortgages), level five times higher than that in February 2006 (when the share of securities backed by mortgages in total was zero). Worldwide, central banks ' assets increased from 5,000-6,000 billion dollars before the global financial and economic crisis to nearly 20,000 billion dollars at present, financial markets becoming so dependent on "money budget".This has led to a Chase after increasing the rate of revenue (or yield) and shifting of significant capital to emerging economies.

In the opinion of international experts, reducing the degree of relaxation of the monetary policy of the USA will be accompanied by the withdrawal of liquidity in dollars on global markets, which will further highlight the structural problems and the imbalances in the world economy. The process of reform in order to enhance the competitiveness of developed economies are far from being completed and, at the same time, the debt (public and private) in these countries (as share in GDP) has reached unprecedented levels.

Under the current phase of quantitative easing, the FED has purchased each month government bonds and mortgage-backed securities, in order to keep the cost of credit at a reduced level and give an impetus to economic recovery and the creation of new jobs. As the unemployment rate has entered on a downward slope in the latter part of last year (7percent in November and 6.7 percent in December 2013-levels still high compared to an unemployment rate of $4.4 \%$ in 2007), has been reduced and the amount of securities purchased. Thus, in December 2013, it was decided to drop the value of purchases from 85 billion dollars per month to 75 billion dollars per month, and in January 2014 a new drop to 65 billion dollars per month ( $\$ 30$ billion mortgage plus $\$ 35$ billion in government securities).

International experts expect that at the next meeting of the federal Committee for financial stability (FOMC) under the EDF, the degree of relaxation of monetary policy should be reduced even further, and some analysts even warned that this year's monetary incentives might be withdrawn entirely. 


\author{
(online) $=$ ISSN $2285-3642$ \\ ISSN-L = 2285-3642 \\ Journal of Economic Development, Environment and People \\ Volume 4, Issue 2, 2015 \\ URL: $\underline{\text { http://jedep.spiruharet.ro }}$ \\ e-mail: office jedep@spiruharet.ro
}

Emerging economies were "flooded" in recent years by a substantial amount of "cheap"dollars, generated from the monetary policy of the FED and are in search of high returns. According to the Institute for international finance, the amounts drawn from these economies through foreign direct investment but also investment in bonds and shares amounted to $\$ 7$ trillion in 2005-2013. Exchange-traded funds (ETF) amounted to $\$ 300$ billion in 2013, the three-time value recorded in 2008 , compared with a value close to zero in 2004. The tools meant to facilitate the inflows of "hot money" into emerging economies during periods of boom were also a rapid output channel for this capital during periods of slowdown of economic growth paces.

A few years ago, the Brazilian Minister of finance Guido Mantega, accused the developed countries of the initiation of a "currency war", the quantitative relaxation being equivalent to the depreciation of the dollar and, at the same time, discouraging exports with emerging markets in developed countries. In turn, quantitative relaxation the braking is a threat, being equivalent to the US. Government bonds fall in commodity prices and decreased demand for assets in emerging markets.

\title{
7. Reducing disparities, a target difficult to achieve
}

The report of the Oxfam Development Organization, released on January 20, 2014 and called "Working for those few" shows that almost half of the global wealth is in the hands of $1 \%$ of the planet's population. Their wealth is estimated at 110,000 billion dollars. Moreover, 85 people have a wealth similar to the one owned by half of the world's population. According to a Bloomberg index that most wealthy possessions accounted for 300 people of the planet, on the whole, their fortunes have reached 3,700 billion dollars in 2013 , which means an increase of $\$ 524$ billion in justone year, of the 300 , only 70 have experienced a loss.

According to the U.S. Census Bureau, income inequality in this country has been growing for several decades. The poverty rate was $15 \%$ in 2012 , and the number of poor people has reached 46.5 million. A quarter of young people under 18 are below the poverty line.

The above mentioned Oxfam report shows that even before the outbreak of the global financial and economic crisis in several countries in the EU were registered increases in income inequalities. Portugal and the United Kingdom are among the most "unequal" countries from among the Member countries of the Organization for economic cooperation and development (OECD). Austerity programmes being implemented in most countries of the community led to the expected results in terms of economic recovery and decreased social gaps, a fact evidenced by the statistics: the wealthiest $10 \%$ increased their share in the total revenue. The summary of the most wealth wealthy European exceeds ten economic stimulating measures adopted in the EU between 2008 and 2010 (217 billion Euros compared to 200 billion Euros).

Cardinal Peter Turkson, President of the Pontifical Council for peace and justice, read the Pope's message for the world leaders at the opening ceremony of the world economic forum, the basic idea being that wealth should serve humanity, not lead it, requiring mechanisms aimed at helping the poor, so that they can get out of the situation of social assistance. 


\author{
(online) $=$ ISSN $2285-3642$ \\ ISSN-L = $2285-3642$ \\ Journal of Economic Development, Environment and People \\ Volume 4, Issue 2, 2015 \\ URL: $\underline{\text { http://jedep.spiruharet.ro }}$ \\ e-mail: office jedep@spiruharet.ro
}

Ban Ki-moon, the UN Secretary-General reminded that 2015 is the deadline for the achievement of the Millennium Development Goals (MDGs) and it is necessary to define a development agenda for the post2015 period. In his turn, the World Bank President Jim Yong Kim, drew the attention to the social inequalities.

\title{
8. Unemployment
}

The International Labor Organization Report called "Trends in global employment", published on 21 January 2014, shows that the global unemployment rate was 6 percent last year,when about 202 million people were without jobs ( 5 million increase compared to 2012). Of these, 74.5 million were young people under 24 years of age (up to 1 million by 2012), which has lifted the unemployment rate among young people at $13.1 \%$. There is a category of young people who neither work nor benefit from education and training (neither in employment nor in education, or training-NEET), in some countries a quarter of young people aged between 15 and 29 years old belonging to this category. In the year2013, 375 million employees (almost $12 \%$ of the total) were living on less than 1.25 dollars a day, and 839 million employees (26.7\% of the total) with less than $\$ 2$ a day. For 2018 it is foreseeable that about 215 million people will be unemployed worldwide. Each year it is necessary to generate about 42 million jobs for the new entrants on the labour market. Currently, the largest share of new job seekers focus in East Asia and the South (45\% of the total),followed by sub-Saharan Africa and Europe.

Guy Ryder, Director-general of the International Labour Organization drew the attention to the fact that, after leaving the Swiss mountain resort, the leaders who attended the summit should focus on those who were not in Davos, among them being: the unemployed who are looking for a job, the employees who need a decent salary, business travelers who need access to credit. The issue of jobs is "the gorilla of the Salonin Davos", and this cannot be ignored, but must be addressed.

\section{Conclusions}

Currently there is a lack of consistency of the European model, observed by the division of the EU members into two categories, creditor countries and debtor countries, in countries with stable economic growth and low cost of financing and countries with serious problems such as Portugal, Spain, Italy etc. How could one consider entering a virtuous circle in Europe,given that it has 27 million unemployed citizens, an average unemployment rate in the Euro area of $12 \%$ and member countries such as Greece and Spain which have a $25 \%$ unemployment rate and nearly 60 percent unemployment rate among young people? The sensation of recoil is powerful and can be seen from the fact that Italy's per capita income decrease to the one it had in 1998 , and the Euro area average decreased to the figure from six years ago.

The European decisions seem to belong to an elite club governing from a distance", suffering from information asymmetry and serious incapacity of reducing the in temporal gaps, in ,supporting and implementing the decision on the problem-solving solutions.

It is clear. The following crisis at European level will be a political one, , quickly followed by a social crises. Maintaining the status quo does not deserve to be a scenario to consider. 2014 will be the year of decision. If the European project will go ahead in its current form is a good question. I believe that the 


\author{
(online) $=$ ISSN $2285-3642$ \\ ISSN-L = 2285-3642 \\ Journal of Economic Development, Environment and People \\ Volume 4, Issue 2, 2015 \\ URL: $\underline{\text { http://jedep.spiruharet.ro }}$ \\ e-mail: office jedep@spiruharet.ro
}

answer is no and that structural reforms and measures should be implemented quickly. 1800 regulations directives and decisions per year seems to me too many, an average cost of 2,300 euros for starting a business - almost 4 times more than in the USA and 15 times less than in Canada seems to me tremendous. Not being aware, for example, that the refining and petrochemical sectors contribute to national budgets with more than 250 billion euros and nonetheless it is left to die seems to me unbelievable. And more than that, spending 180 billion euros for climate policies and hesitating to provide 8 billion euros to reduce unemployment among young people is not very logical.

However, a coherent action in 2014 can restore hope among European countries. In parallel with the fiscal consolidation (defined as predominantly qualitative adjustment, based on better management of public spending, through prioritization and transfer of funding from European funds, restructuring of state companies, increasing transparency in public spending, increasing the tradables sector even through deep transformation of rural areas, etc.) it is necessary to reshape Germany's policies, as it is the main motor of European integration. Forced by the continuing fiscal consolidations and commitment of countries with problems in compliance with the rules imposed by the Fiscal Compact and the European Semester, Chancellor Merkel will probably accept the rise of wages by 1.5 to 2 percentage points above the rate of growth of labour productivity, an increase in domestic demand, default and anchor for tradable goods manufactured in southern countries. Germany will witness an increasing trend anyway, the risk that the country's economic growth shall reach its limits being higher than the net excess inflation generated by increasing salaries over the labour productivity growth rate.

The ECB will restructure its policy of injecting money into the economy, taking into account the risk that reducing interest rates shall generate a much smaller cost of capital relatively to labor and consequently a high structural unemployment. The forcing of the European construction with a Banking Union (common prudential system, common guarantee system and unified mechanism to solve the banking crisis potential) as antidote to banking run, completed with the issuance of Eurobonds, the relaxation of stimulation mechanisms for industrial policies and a Pact for economic growth could take EU out of the vicious circle where it is positioned now.

A budget and a common mechanism of asymmetric shocks in the depreciation of Euro zone countries (lacking macroeconomic adjustment tools) seems unavoidable.

Last but not least, the EU should set up a Fund for economic growth and development of infrastructure for the cohesion countries, a Fund which will be made up of the liabilities existing on Dec. 31, 2013 for certain types of projects (e.g., those related to infrastructure and the environment but also for the development of human resources). From this Fund, the initial connection to the trans-European infrastructure networks, education, research will be financed., etc.

The European model must return to the initial objectives-economic growth, solidarity and welfare growth. Economic stagnation for an area that represents one-quarter of the world GDP cannot be but troubling news. Otherwise, the gap between it and the US model, with a strong growth fueled by the gas system, revolution will grow deeper. 


\author{
(online) = ISSN $2285-3642$ \\ ISSN-L = 2285 - 3642 \\ Journal of Economic Development, Environment and People \\ Volume 4, Issue 2, 2015 \\ URL: http://jedep.spiruharet.ro \\ e-mail: office jedep@spiruharet.ro
}

\title{
10. References
}

[1] Alexandru T. Bogdan and co-authors (2010), Prospects of Agrifood Green Power in 2050 and Forecasting for 2100 with Sustenable Solutions Based on Ecobioeconomics new Paradigm, Bulletin UASVM Animal Science and Biotechnologies, 67 (1-2)/2010;

[2] Cohen, D. şi Soto, M. (2011), Growth and Human Capital: Good Data, Good Results, Development Centre Technical Papers No.179, OECD;

[3] De la Fuente, A. şi Doménech, R. (2006), „Human Capital in Growth Regressions: How Much Difference Does Data Quality Make?". Journal of the European Economic Association. Vol.4, No.1, pp.1-36;

[4] Dictionary, The New Palgrave Dictionary of Economics(2008), 2nd edition, Palgrave Macmillan, Basingstoke, Hampshire.

[5] Dipl. Eng. Dana Comşa, Prof. Univ. Ph.D. Dr. H. C. Alexandru T. Bogdan, Correspondent Member To The Romanian Academy, Eco-Bio-Diplomacy A New Concept For A Smart Sustainable Development In A Globalized World In The Context Of The Eco-Bio-Economy (2013), Bulletin UASVM Animal Science and Biotechnologies, 78 (1-2)/2013;

[6] DPAD, United Nationas Report - World Economic Situation and Prospects mid -2014 (2014), United Nations;

[7] IIF, Institute of International Finance (2014), The Global Association of Financial Industry, Global Economic Monitor;

[8] ILO, Global Employment Trends 2013- Recovering from a second jobs dip (2013), International Labour Organisation, Geneva;

[9] IMF, Energy Subsidy Reform. Lessons and Implications, (2013), Philippe Karam, International Monetary Found;

[10]IMF, World Economic Qutlook (WEO) - Recovery Strenghtens, Remains Uneven, (2014), International Monetary Found;

[11]OECD (2013), The Well-being of Nations. The Role of Human and Social Capital, Centre for Educational Research and Innovation, OECD Publications, Paris.

[12]OECD (2013), The Well-being of Nations. The Role of Human and Social Capital, Centre for Educational Research and Innovation, OECD Publications, Paris.

[13]Oxfam Briefing Paper (2014), Working for the few - Political Capture and Economic Inequality, 20 January;

[14]UNDP, Human Development Report 2014 (2014), Sustaining Human Progress: Reducing Vulnerabilities and Building Resilience, New York, USA ;

[15]United States Census Bureau, USA, 2014;

[16]World Bank, WB Annual Report 2014 - The Perspectives of Global Economy, Poverty vs. Prosperity, The World Bank, 2014

[17]World Bank, Global Risks Raport 2014 (2014), Ninth Edition, World Economic Forum, Davos;

[18]World Economic Forum (2013), The Global Information Technology Report 2013, Geneva - World Economic Forum. 